\title{
To Purchase or to Rent a Home in Malaysia? A Case Study in Selangor
}

\author{
Chia Mei Si ${ }^{1}$, Wei Chooi Yi ${ }^{2}$ \\ 1,2Faculty of Business and Finance, Universiti Tunku Abdul Rahman, Malaysia \\ chiams@utar.edu.my,weicy@utar.edu.my
}

DOI: https://doi.org/10.37134/jcit.vol8.1.2018

\begin{abstract}
The real estate sector in Malaysia has witnessed rapid growth, especially in the residential and commercial segments. This study aims to determine the significant factors leading to the intention to either purchase or rent a house in Malaysia. Demographic factors, financial assessment and social attributes serve as independent variables for decision making concerning purchase or rental of a house. The Rational Choice Theory is applied in this study. Data collected via questionnaire to households' in several shopping malls in Selangor. The findings reveal that educational qualification and households' monthly income influence the intention to purchase or rent a house while marital status is not a significant determining factor. Respondents with higher educational qualification and higher household monthly income prefer to purchase a residential property rather than to rent. Financial assessment is a significant factor affecting the intention to purchase or rent a residential property. Implication of this study enables government, bankers, marketers and real-estate developers to take into consideration of demographic factors, financial assessment and social attributes for future strategies formulation toward real estates development in Malaysia.
\end{abstract}

Keywords: decision making, demographic, financial assessment, social attributes, real estate

\section{INTRODUCTION}

The modern and highly globalized societies have witnessed a rapid growth of various industries. An example is the construction industry in Malaysia. Transnational properties have proliferated significantly in line with globalization (Sanghoon, Huynh \& Rowe, 2013) and the marked increase in population. Malaysia, as a developing country, had a population of 30,995.7 million in 2015. As for the states in Malaysia, Selangor had the highest population with 6,140.1 million people, followed by Sabah, 3736.2 million; Johor, 3547.7 million; Perak, 2,457.8 million and Sarawak 2,707.6 million. The increase in population led to a rise in demand for basic needs such as food, water and shelter. Asiah (1999) stressed that housing is a basic need for every citizen and this is acknowledged by the Malaysian government. Thus, it is evident that an increase in a country's population results in a significant rise in the demand and supply of residential properties.

According to Mahmood and Zakaria (2007), the property sector has played a significant role in the economic development of Malaysia. Ong (2013) pointed out that a rapid increase in demand and supply of residential properties would lead to an escalation in the value of the properties. This phenomenon is also known as the 'housing bubble', where a surge in demand and supply of houses lead to continuous increase in property prices over a period of time. In terms of the cost of borrowing, prior to the implementation of the Base Rate (BR), cost of obtaining housing loans from local financial institutions was 6.68\% Base Lending Rate (BLR) rate minus 2.4\% (bank rate) (Chin, 2014). In March 2014, 
the Central Bank of Malaysia (Bank Negara Malaysia) (BNM) announced that the BLR, which is determined by BNM, would be replaced by Base Rate (BR), effective January 2015. The BR is determined by the financial institutions' benchmark cost of funds (Chai, 2015).

As stated in the 11 $11^{\text {th }}$ Malaysia Plan (2016-2020), the Government's intention is to increase affordable housing to the poor, low and middle income households in urban and rural areas. In addition, financing schemes such as My First Home Scheme, Youth Housing Scheme (YHS) and MyHome are extended to prospective home buyers and developers. My First Home Scheme was announced by the government in budget year 2011 and is targeted at assisting young adults own a house. Under this scheme, home buyers are able obtain $100 \%$ financing from financial institutions. Thus, the down payment of $10 \%$ is waived.

Meanwhile, the Youth Housing Scheme (YHS), which was announced in the budget year 2015, allows married house buyers within the age group 25 to 40 years with monthly income of not more than RM10,000 to purchase their first residential property. Under this scheme, a $50 \%$ exemption of stamp duty on the transfer and loan agreements is provided as well as RM200 per monthly assistance is given for a period of 2 years from the date of first disbursement of loan to the developer to subsidize repayment installments. In the case of the MyHome program, the government offers incentive up to RM30,000 per unit. In 2014, an allocation of RM300 million for building 10,000 units of affordable homes around the country was provided. Together with the My Deposit program newly launched in April 2016, all these initiatives constitute the various incentives made available by the Government to increase ownership of residential property, the target being at least one house per household.

Despite the several incentives from government and sales offers from developers, most households still deliberate when it comes to deciding whether to purchase or rent a house for their living. This issue led to a research gap to be investigated though this exploratory study by exploring the following research questions:

i) What is the most significant factor leading to the intention to purchase a residential property in Malaysia?

ii) What is the most significant factor leading to the intention to rent a residential property in Malaysia?

\section{REVIEWS ON LITERATURE}

Several past studies have dwelt on intentions pertaining to property holding (Jayakumar \& Velmurugan, 2016; Ong, 2013; Reid, 2013; Jain \& Mandot, 2012; Iman, Pieng \& Gan, 2012; Lutfi, 2011; Barber \& Odean, 2000 and Swan, 1995). Yet, there are very few that examined the reasons or factors leading to the intention to purchase or rent a residential property.

\section{Demographic factors}

According to Jain and Mandot (2012), one of the main factors that influence people when making purchasing decisions regarding property holding is demography. This encompasses marital status, gender, age, education level, annual income, members of 
household and employment. The higher the annual income of a person, the availability and the intention to purchase a property would be greater. Lutfi (2011) affirmed that marital status does influence the decision of an individual to hold a residential property. Further, based on the studies by Barber and Odean (2000), it was noted that the risk tolerance of male investors is higher than that of female investors. This finding shows that male investors tend to be more self-confident in making decisions. Iman et al. (2012) pointed out that the types of property and different costs involved lead to different selling prices. Meanwhile, Swan (1995) mentioned that the age group also affects the intention to purchase a residential property. Mostly, the younger generation in the below 30 years age group are unable to own a house due to their financial instability. Therefore, the intention to purchase or rent a residential property highly correlates with the demographic factors.

\section{Financial Assessment}

Presently, there are several promotions and rebates from developers, banks, government and real estate agents to attract investors to own property. Iman et al. (2012) highlighted promotional efforts such as launching day special offer, rebate on down payment and several discounts on properties', all directed towards influencing the prospective house buyers. Paco and Raposo (2009) mentioned that the financial factor plays a very significant role in purchasing decision making. Numraktrakul, Ngarmyarn and Panichpathom (2012) also concurred that finance greatly influences an individual when considering property ownership, given the quantum of housing loan involved. The usual mode of financing of a property is bank loans. An increase in demand for housing properties lead to a rise in demand for housing loans (Ong, 2013). Thus, cost of borrowing, income, repayment ability, loan amount, term of the loan and the housing price most probably influence an individual's decision making to own a property.

Hence, people tend to rent a house rather than own a property after considering the financial factor (Reid, 2013). People would shift from renting to owning when they achieve economic stability and feel the need to invest for accumulating wealth or when they believe that owning a residential property provides a better life for their children. On the other hand, Jayakumar and Velmurugan (2016) stated that as there are fewer properties available for rent, the consequent increase in rental fees causes the demand for owning a property to rise. They further mentioned that people would prefer to pay for housing loan rather than rental fees should there be not much difference in those liabilities.

\section{Social Attributes}

A property could be owner-occupied or rented (Issac, 1998). Given the increase in population growth in Malaysia, more houses are needed for people to live. However, several factors determine where they want to live. According to Vermeulen and Van Ommeran (2006), people tend to buy or rent a house in an area nearby to their working place. Other attributes that influence an individual's decision making include pricing, location, built-up area, property design, developer's reputation, promotions, security and facilities (Iman et al., 2012). The decision making is also influenced by the opinions of 
people who are closely affiliated such as spouse, family members, friends and colleagues (Iman et al., 2012; Makgosa \& Mohube, 2007).

\section{THEORY AND METHODOLOGY}

Rational Choice Theory is applied in this study. According to Levin and Milgrom (2004), rational choice refers to the process of determining the most preferred option while taking into account other relevant factors such as demographic factors, financial assessments and social attributes.

This exploratory study aims to obtain households' perception towards their decision making to purchase or rent a residential property in the state of Selangor, Malaysia. From the respondents' perceptions, the researcher was able to identify the most significant factor affecting the household's intention to purchase or rent a residential property the state of Selangor, Malaysia.

\section{Population and Sample}

The population of Malaysia currently totals 30,995.7 million people. According to Krejcie and Morgan (1970), based on a population size of more than 10,000, the approximate sample size would be 384 . Thus, 400 questionnaires were distributed via convenience sampling technique to households in several shopping malls in the states of Selangor. Completed questionnaires of 390 sets were keyed into Statistical Package for Social Science (SPSS) version 22 to generate the results to answer the research questions.

\section{Data Collection}

To obtain the data, a set of questionnaire was developed by researchers from past studies and distributed to households' in several shopping malls in the state of Selangor. The questionnaire consists of 3 sections. Section A was developed to gather the respondent's demographic information such as gender, age, marital status, educational qualification and households' monthly income. Section B contains 8 items for the construct of financial assessment and section $\mathrm{C}$ comprises 8 items for social attributes.

\section{RESULTS}

As shown in Table 1, there were 204 male (52.3\%) and 186 (47.7\%) female respondents. It was observed that out of the 204 males, 132 preferred to purchase a residential property whereas 72 males wished to rent it. 
Table 1: Demographic Profile of Respondents

\begin{tabular}{|c|c|c|c|c|c|}
\hline & & \multirow{2}{*}{$\begin{array}{l}\text { Purchase } \\
\text { n }\end{array}$} & \multirow{2}{*}{$\begin{array}{l}\text { Rent } \\
\mathrm{n} \\
\end{array}$} & \multicolumn{2}{|c|}{ Total } \\
\hline & & & & $\mathbf{n}$ & $\%$ \\
\hline \multirow[t]{2}{*}{ Gender } & Male & 132 & 72 & 204 & 52.3 \\
\hline & Female & 111 & 75 & 186 & 47.7 \\
\hline \multirow[t]{3}{*}{ Age } & $25-29$ & 20 & 49 & 69 & 17.7 \\
\hline & $30-34$ & 93 & 76 & 169 & 43.3 \\
\hline & $35-39$ & 130 & 22 & 152 & 39.0 \\
\hline \multirow[t]{2}{*}{ Marital Status } & Single & 109 & 61 & 170 & 43.6 \\
\hline & Married & 134 & 86 & 220 & 56.4 \\
\hline \multirow{7}{*}{$\begin{array}{l}\text { Educational } \\
\text { qualification }\end{array}$} & Primary school & 7 & 12 & 19 & 4.9 \\
\hline & Secondary school & 51 & 38 & 89 & 22.8 \\
\hline & Degree & 52 & 51 & 103 & 26.4 \\
\hline & Master & 55 & 14 & 69 & 17.7 \\
\hline & $\mathrm{PhD}$ & 18 & - & 18 & 4.6 \\
\hline & Professional & 60 & 32 & 92 & 23.6 \\
\hline & Certificates & & & & \\
\hline \multirow{6}{*}{$\begin{array}{l}\text { Households' } \\
\text { monthly income }\end{array}$} & Less than RM2000 & - & 45 & 45 & 11.5 \\
\hline & RM2000 - RM2999 & 20 & 49 & 69 & 17.7 \\
\hline & RM3000 - RM3999 & 50 & 23 & 73 & 18.7 \\
\hline & RM4000 - RM4999 & 72 & 30 & 102 & 26.2 \\
\hline & RM5000 - RM5999 & 54 & - & 54 & 13.8 \\
\hline & $\begin{array}{l}\text { RM6000 and } \\
\text { above }\end{array}$ & 47 & - & 47 & 12.1 \\
\hline
\end{tabular}

As for the females, 111 respondents preferred to purchase a residential property, while 75 wished to rent it. In terms of age, 130 respondents in the age group $35-39$ preferred to purchase a house. The reason being most of the respondents in this age group obtained financial support given their stable monthly income. Regardless of the respondents' marital status (109 respondents were single and 134 respondents were married), most of them preferred to purchase a residential property. This finding reveals that marital status is not a significant factor influencing the intention to purchase or rent a house. In terms of educational qualification and households' monthly income, respondents with higher educational qualification and higher household monthly income favored the purchase of a residential property as against renting it.

Table 2: Means and Standard Deviation for each Construct (Intention to Purchase)

\begin{tabular}{llll}
\hline Variables & N & Mean & Standard deviation \\
\hline Financial assessment & 243 & 3.531 & 0.392 \\
Social attributes & 243 & 3.036 & 0.423 \\
\hline
\end{tabular}

For the significant factors leading to the intention to purchase a residential property as shown in Table 2, analysis of mean $=3.531, \mathrm{SD}=0.392$ reveals that financial assessment serves as the most significant factor affecting the intention to purchase a residential 
property. Furthermore, significant factors leading to the intention to rent a residential property as shown in Table 3, analysis of mean $=3.558, \mathrm{SD}=0.389$ indicates that financial assessment serves as the most significant factor in influencing the intention to purchase a residential property.

Table 3: Means and Standard Deviation for each Construct (Intention to Rent)

\begin{tabular}{llll}
\hline Variables & $\mathbf{N}$ & Mean & Standard deviation \\
\hline Financial assessment & 147 & 3.558 & 0.389 \\
Social attributes & 147 & 3.183 & 0.410 \\
\hline
\end{tabular}

\section{DISCUSSION AND CONCLUSION}

It could be concluded that demographic factors, educational qualification and households' monthly income influence the intention to purchase or rent a residential property. A significant factor determining the above intention is financial assessment. The findings of this study are supported by previous studies such as by Jayakumar and Velmurugan (2016), Ong (2013), Reid (2013), Numraktrakul et al. (2012), Iman et al. (2012), Paco and Raposo (2009). Financial factor plays a vital role in deciding whether to own a property as it involves a large commitment in terms of the quantum of housing loan. Thus, cost of borrowing, income, repayment ability, loan amount, terms of the loan and the housing price would most probably influence their decision making. Implication of this study enables government, bankers, marketers and real-estate developers to take into consideration of demographic factors, financial assessment and social attributes for future strategies formulation toward real estates development in Malaysia.

\section{REFERENCES}

Asiah Othman. (1999). The effect of the planning system on housing development: A study of the development: A study of developers behavior in Kuala Lumpur and Johor Bahru, Malaysia. University of Aberdeen: Ph.D. Thesis.

Barber, B. M. \& Odean, T. (2000). Trading is hazardous to your wealth: The common stock investment performance of individual investors. The Journal of Finance, 55(2), 773-806.

Chai, D. (2015). BLR to Base Rate: What Does This Mean For Your Home-Buying Dreams? Accessed on $10^{\text {th }}$ April 2016. Retrieved from https://ringgitplus.com/en/blog/Home-Loans/BLR-to-Base-Rate-What-DoesThis-Mean-For-Your-Home-Buying-Dreams.html

Chin, R. (2014). Home Loan issues, Malaysian Fixed Rate Home Loan, Properties. Accessed on 7th April 2016. Retrieved from http://homeloaninsurance.com.my/will-based-lending-rate-malaysia-blr-rate-increase/

Iman, A. H. M., Pieng, F. Y. \& Gan, C. (2012). A conjoint analysis of buyers' preferences for residential property. International Real Estate Review, 15(1), 73-105.

Isaac, D. (1998). Property investment (pp. 1-27). UK: Macmillan Education.

Jain, D. \& Mandot, N. (2012). Impact of demographic factors in investment decisions of investors in Rajasthan, Researchers' World, 3(2), 81.

Jayakumar, N. \& Velmurugan, R. (2016). Acquirer's preference in the purchase of housing property with reference to Coimbatore. Global Journal for Research Analysis, 5(2).

Krejcie, R.V. \& Morgan, D.W. (1970). Determining sample size for research activities. Educational and Psychological Measurement, 30, 607-610.

Levin, J. \& Milgrom, P. (2004). Introduction to Choice Theory, Curriculum Notes. Retrieved from http://www.milgrom.net/ 
Lutfi, L. (2011). The relationship between demographic factors and investment decisions in Surabaya. Journal of Economics, Business and Accountancy Ventura, 13(3), 213-224.

Mahmood, W. \& R. Zakaria. (2007). Profitability and capital structure of the property and construction sectors in Malaysia, Pacific Rim Property Research Journal, 13, 92- 105.

Makgosa, R. \& Mohube, K. (2007). Peer influence on young adults' product purchase decisions. African Journal of Business Management, 1(3), 64.

Numraktrakul, P., Ngarmyarn, A. \& Panichpathom, S. (2012). Factors Affecting Green Housing Purchase. In 17th International Business Research Conference. Toronto, Canada.

Ong, T. S. (2013). Factors affecting the prices of housing in Malaysia. Journal of Emerging Issues in Economics, Finance and Banking, 1(5), 414-429.

Paco,A. \& Raposo, M. (2009). “Green” segmentation: an application to the Portuguese consumer market. Marketing Intelligence \& Planning, 27(3), 364-379.

Reid, C. (2013). To buy or not to buy? Understanding tenure preferences and the decision-making processes of lower-income households. Cambridge, MA: Joint Center for Housing Studies of Harvard University.

Sanghoon, J., Huynh, D. \& Rowe, P. G. (2013). The pattern of foreign property investment in Vietnam: The apartment market in Ho Chi Minch City. Habitat International, 39, 105-113.

Swan, C. (1995). Demography and the demand for housing-A reinterpretation of the Mankiw-Weil demand variable. Regional Science and Urban Economics, 25(1), 41-58.

Vermeulen, W. \& Van Ommeran, J. (2006). Housing supply and the interaction of regional population and employment (No.65). CPB Netherlands Bureau of Economic Policy Analysis. 